\title{
Erratum to: Surface display of an anti-DEC-205 single chain Fv fragment in Lactobacillus plantarum increases internalization and plasmid transfer to dendritic cells in vitro and in vivo
}

Christophe Michon ${ }^{1,2}$, Katarzyna Kuczkowska ${ }^{3}$, Philippe Langella ${ }^{1,2}$, Vincent G. H. Eijsink ${ }^{3}$, Geir Mathiesen ${ }^{3}$ and Jean-Marc Chatel ${ }^{1,2^{*}}$

\section{Erratum to: Microb Cell Fact (2015) 14:95 DOI 10.1186/s12934-015-0290-9}

Unfortunately, the original version of this article [1] contained an error. The name of the author was incorrectly written as Michon Christophe. The correct writing is Christophe Michon.

\section{Author details}

${ }^{1}$ INRA, UMR1319 MICALIS, Bat 440, R-2, 78352 Jouy-en-Josas, France.

${ }^{2}$ AgroParisTech, UMR MICALIS, 78352 Jouy-en-Josas, France. ${ }^{3}$ Department of Chemistry, Biotechnology and Food Science, Norwegian University of Life Sciences, Aas, Norway.

The online version of the original article can be found under doi:10.1186/s12934-015-0290-9.

Received: 22 October 2015 Accepted: 22 October 2015

Published online: 17 November 2015

*Correspondence: jean-marc.chatel@jouy.inra.fr

${ }^{1}$ INRA, UMR1319 MICALIS, Bat 440, R-2, 78352 Jouy-en-Josas, France

Full list of author information is available at the end of the article

Reference

1. Christophe M, Kuczkowska K, Langella P, Eijsink VGH, Mathiesen G, Chatel J-M. Surface display of an anti-DEC-205 single chain Fv fragment in Lactobacillus plantarum increases internalization and plasmid transfer to dendritic cells in vitro and in vivo. Microb Cell Fact. 2015;14:95.

\section{C) provided you give appropriate credit to the original author(s) and the source, provide a link to the Creative Commonslicense, and indicate if changes were made. The Creative Commons Public Domain Dedication waiver (http://creativecommons.org/ publicdomain/zero/1.0/) applies to the data made available in this article, unless otherwise stated. 